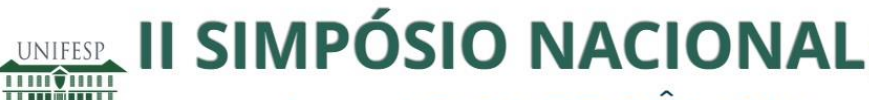

\section{Adolescência e vulnerabilidade: o Coringa como símbolo}

\author{
Thalita Araújo de Campos Arruda \\ Universidade Presbiteriana Mackenzie \\ Faculdade de Ciências da Saúde \\ E-mail: tcamposarruda@gmail.com
}

\begin{abstract}
Como citar:
ARRUDA, Thalita Araújo de Campos. Adolescência e vulnerabilidade: o Coringa como símbolo. In: II SIMPÓSIO NACIONAL SOBRE ADOLESCÊNCIA: VULNERABILIDADE, PROTAGONISMOS E DESAFIOS, 2. 2016, São Paulo. Anais...[S.I]: 2016. p. 32.

DOI: http://dx.doi.org/10.22388/2525-5894.2016.009
\end{abstract}

A autora discorre sobre o desenvolvimento de adolescentes em situação de vulnerabilidade social através de um trabalho em grupo com indivíduos entre 12 e 14 anos de idade e com comportamento agressivo. No processo grupal, campo de exploração dos aspectos individuais e coletivos, os jovens deram forma a máscaras de argila do Coringa, vilão do filme do Batman. O Coringa é um jogador em quem não se pode confiar e ninguém sabe sua real origem. Considerando-o como símbolo, amplia a discussão para além do grupo atendido e busca a compreensão do desenvolvimento da adolescência a partir da articulação entre os aspectos que atravessam essa etapa da vida e a desigualdade social. Uma compreensão simbólica que investiga o significado psicológico do mal para o adolescente em vulnerabilidade social, proporcionando um contato com a sombra individual e coletiva. Utiliza como embasamento teórico a psicologia analítica sugerida por Carl Gustav Jung (1875-1961) e a arteterapia. A primeira confia que o desenvolvimento da personalidade acontece através de um processo de diferenciação, elaboração de conteúdos sombrios e transformação de consciência na expressão artística como fonte de conteúdos inconscientes. Na arteterapia os materiais artísticos são utilizados como facilitadores da expressão de símbolos dos aspectos inconscientes que provocam uma relação entre os conteúdos da psique. A argila foi o recurso que deu materialidade aos confrontos da psique através da máscara do Coringa e permitiu que a sombra, repleta de aspectos inconscientes em relação ao ego, fosse percebida e assimilada. Realiza uma análise do valor simbólico do Coringa em relação às transformações psíquicas e à sociedade, utilizando como método os grupos vivenciais e comprovando que o mesmo favorece o confronto com aspectos individuais e coletivos. Considerando as condições psíquicas que a exclusão social desperta, os significados que emergem desta dinâmica em relação aos atravessamentos que envolvem a adolescência e o lugar social que esses jovens ocupam. O Coringa como uma imagem para ser elaborada é uma maneira de atuar em oposição à massificação e destrutividade, o diálogo com essa figura oferece a possibilidade de sair de um estado de fixação e imitação do mal e proporciona o confronto e a discriminação necessários para o amadurecimento 
psíquico. Um olhar para os adolescentes nessa condição social é uma maneira de colaborar com o desenvolvimento humano e elaborar a sombra social, o mal que a sociedade tem e não assume. Essa discussão amplia a reflexão sobre o desenvolvimento da psique e oferece uma tentativa de aprimorar o conhecimento da sociedade, da sombra coletiva, da adolescência e também do mal como característica psíquica. Além de refletir sobre o manejo terapêutico e as possibilidades de intervenção, através de uma compreensão que expande o campo de trabalho terapêutico e busca colaborar com o desenvolvimento da sociedade.

Palavras-chave: Adolescência. Coringa. Símbolo. Sociedade. Vulnerabilidade social. 